\title{
Karl Theodore
}

\section{HIV/AIDS in the Caribbean: Economic Issues, Economic Impact and Financing the Response}

\subsection{Introduction}

The HIV/AIDS epidemic is now well into its third decade of existence and it remains the most serious of infectious disease challenges to public health systems (UNAIDS, 2009). The disease is still spreading at an alarming rate, killing exponentially and threatening to frustrate the process of economic development in many countries and regions, the Caribbean being no exception. This is despite efforts to contain the spread of the disease through regional and national response programmes. However, today much more is understood about the HIV/AIDS than when it first surfaced and as such there are many lessons to be learnt from various country experiences.

When we turn to the Caribbean we find that while just about 1,100 deaths were recorded in the first decade, by the end of the second decade another 7,000 deaths had occurred - an increase of more than 500 per cent. Even if we make allowances for the better recording of deaths in the second decade, the corresponding rates of increases are mind-boggling. Table 1.1 in chapter 1 shows the global prevalence rates of HIV/AIDS and Table 4.1 shows the prevalence rates in the Caribbean, which is second only to sub-Saharan Africa.

At the end of 2008 the HIV/AIDS prevalence in many Caribbean countries was under 1 per cent. Prevalence rates ranged from a low of 1 per cent to just over 4 per cent across the English-speaking Caribbean countries. Taken at face value these rates may not seem to be a large cause for concern. A closer look at the epidemiology of the disease, however, paints a very different picture.

According to La Foucade et al. (2006), there are three aspects of the data that offer a cause for concern: (i) the epidemic is generalised; (ii) new cases are increasing exponentially; and (iii) the existing estimates are very likely to be understated.

UNAIDS defines a generalised epidemic as one with a prevalence rate above 1 per cent, with certain subgroups having rates above 5 per cent. Most of the countries presented in Table 4.1 have prevalence rates above 1 per cent and the latest available data suggests prevalence rates in the vicinity of 30, 40 and 18 per cent respectively among men who have sex with men in Jamaica, Trinidad and Tobago and Suriname.

In Guyana, the prevalence rate among female commercial sex workers was estimated at 31 per cent in 2000, while the corresponding rate for male miners was 6 per cent in 2001 (CAREC, 2002). For pregnant women the rates were 1.4, 3 and 5 per cent in Jamaica, Trinidad and Tobago and 
Table 4.1 HIV statistics (selected Caribbean countries)

\begin{tabular}{|c|c|c|c|c|c|c|}
\hline Country & $\begin{array}{l}\text { Population } \\
2007\end{array}$ & $\begin{array}{l}\text { Adults and } \\
\text { children } \\
\text { living with } \\
\text { HIV/AIDS } \\
2007 \text { (2001) }\end{array}$ & $\begin{array}{c}\text { Adults 15+ } \\
\text { living with } \\
\text { HIV/AIDS } \\
2007 \text { (2001) }\end{array}$ & $\begin{array}{c}\text { Adults } 15-49 \\
\text { prevalence } \\
\text { rate } 2007 \\
\quad(2001)\end{array}$ & $\begin{array}{c}\text { Women 15+ } \\
\text { living with } \\
\text { HIV/AIDS } \\
2007 \text { (2001) }\end{array}$ & $\begin{array}{c}\text { HIV/AIDS } \\
\text { deaths } 2007 \\
\text { (2001) }\end{array}$ \\
\hline The Bahamas & 334,000 & $\begin{array}{c}6,200 \\
(5,700)\end{array}$ & $\begin{array}{c}6,100 \\
(5,600)\end{array}$ & $\begin{array}{c}3.0 \\
(3.1)\end{array}$ & $\begin{array}{c}1,600 \\
(1,300)\end{array}$ & $\begin{array}{c}<200 \\
(<1,000)\end{array}$ \\
\hline Barbados & 255,000 & $\begin{array}{c}2,200 \\
(2,100)\end{array}$ & $\begin{array}{c}2,200 \\
(2,100)\end{array}$ & $\begin{array}{c}1.2 \\
(1.2)\end{array}$ & $\begin{array}{c}<1,000 \\
(<1,000)\end{array}$ & $\begin{array}{l}<100 \\
(<200)\end{array}$ \\
\hline Cuba & $11,202,000$ & $\begin{array}{c}6,200 \\
(2,400)\end{array}$ & $\begin{array}{c}6,200 \\
(2,300)\end{array}$ & $\begin{array}{c}0.1 \\
(<0.1)\end{array}$ & $\begin{array}{c}1,800 \\
(<1,000)\end{array}$ & $\begin{array}{l}<100 \\
(<100)\end{array}$ \\
\hline $\begin{array}{l}\text { Dominican } \\
\text { Republic }\end{array}$ & $9,638,000$ & $\begin{array}{c}62,000 \\
(65,000)\end{array}$ & $\begin{array}{c}59,000 \\
(63,000)\end{array}$ & $\begin{array}{c}1.1 \\
(1.3)\end{array}$ & $\begin{array}{c}30,000 \\
(34,000)\end{array}$ & $\begin{array}{c}4,100 \\
(4,800)\end{array}$ \\
\hline Haiti & $9,605,000$ & $\begin{array}{l}120,000 \\
(98,000)\end{array}$ & $\begin{array}{l}110,000 \\
(94,000)\end{array}$ & $\begin{array}{c}2.2 \\
(2.2)\end{array}$ & $\begin{array}{c}58,000 \\
(43,000)\end{array}$ & $\begin{array}{c}7,200 \\
(7,500)\end{array}$ \\
\hline Jamaica & $2,696,000$ & $\begin{array}{c}27,000 \\
(23,000)\end{array}$ & $\begin{array}{c}26,000 \\
(22,000)\end{array}$ & $\begin{array}{c}1.6 \\
(1.4)\end{array}$ & $\begin{array}{c}7,600 \\
(5,800)\end{array}$ & $\begin{array}{c}1,500 \\
(1,200)\end{array}$ \\
\hline $\begin{array}{l}\text { Trinidad and } \\
\text { Tobago }\end{array}$ & $1,328,000$ & $\begin{array}{c}14,000 \\
(12,000)\end{array}$ & $\begin{array}{c}13,000 \\
(12,000)\end{array}$ & $\begin{array}{c}1.5 \\
(1.4)\end{array}$ & $\begin{array}{c}7,700 \\
(6,900)\end{array}$ & $\begin{array}{c}<1,000 \\
(<1,000)\end{array}$ \\
\hline
\end{tabular}

Source: ECLAC (2010); UNAIDS (2009)

The Bahamas respectively, so some Caribbean territories are already facing a generalised epidemic (CAREC, 2002).

The Caribbean data also indicate that the trend in the total number of HIV+ cases as well as the trend in new cases has been increasing exponentially. The same is true for AIDS cases. An increase in the total number of HIV cases, all other things being equal, could be attributed to a decrease in the mortality rate due to AIDS on account of better access to anti-retroviral treatment. But this is not the case. Both the prevalence rates and the new infection rates are increasing exponentially. This means that although the prevalence rates are not as extreme as in some other places there is still great cause for concern.

The gender distribution of HIV cases is also changing with an acceleration of new cases among females, indicating that females are contracting the virus faster than males. The age distribution of the disease also indicates that the 15 to 44 age group is the one that is most affected, including as it does those individuals who should be at the peak of their life span in terms of productivity. In the Caribbean, HIV/AIDS is still the leading cause of death in this age group and HIV/AIDS cases are observed at every point along the age spectrum. This implies a great negative impact on the present and future productive capacity of these countries.

And finally, to make matters even worse, there is the strong possibility of under-reporting of cases due to stigma and discrimination. There is reason to believe that there are many cases of HIV in developing countries that go unreported and that the surveillance system in many developing countries might not be capturing the majority of HIV/AIDS cases.

In the context of the HIV/AIDS epidemic described above, broadly speaking, the objective of this study is four-fold: 
- To identify the main economic issues associated with HIV/AIDS in small states with specific reference to the Caribbean,

- To explore the impact of HIV/AIDS at both the micro and macro levels,

- To identify any regional best practices which would assist other countries in coping with the epidemic, and

- To review the sources and the extent of financial support directed toward the response to HIV/ AIDS in the Caribbean.

An important component of this chapter will be an attempt to outline the impact of the HIV/AIDS pandemic on the economies of the English-speaking Caribbean. Quite a bit of work has already been done in this area. Previous studies largely analyse the impact of the disease on the macroeconomic variables. One aim of this study would be to synthesise the evidence on the macroeconomic impact and to comment on the effectiveness of the response to the epidemic by the region.

In the Caribbean there has not been much work done on the microeconomic implications of the epidemic. There is macroeconomic research on a few countries which has yielded estimates of the impact of the epidemic at this level. However, there is growing concern that more needs to be known about how individuals who are affected and infected can still enjoy comparable life expectancies and contribute to overall output. The research agenda for the future will need focus on the microeconomic conditions under which these individuals live and the impact on the choices they make.

\subsection{Economic issues raised by HIV/AIDS: impact and response}

A vicious cycle of high prevalence rates and economic depression is evident in the bi-directional relationship between HIV/AIDS and the economy. HIV/AIDS impacts on the economic system and the economy in turn affects the epidemic. A depressed economy could provide ideal breeding conditions for the spread of the disease which in turn would further depress the economy. The epidemic surfaced in the Caribbean in the early 1980s. At this time many economies of the region were already in a state of depression and health systems far-stretched for lack of capacity. The emergence of HIV/AIDS threatened to worsen the economic and social conditions of these already fragile economies.

According to Theodore (2000), there are essentially four channels through which the HIV/AIDS epidemic could potentially exert economic impacts in the Caribbean. These are the production, allocation, distribution and regeneration channels.

\subsubsection{The production channel}

This channel describes the mechanisms by which the disease impacts on the main factors of production - labour and capital - causing the production process to be less fruitful than it would otherwise have been. The epidemic impacts on labour when individuals are infected at the most productive stage of their lives. The labour supply of the economy is reduced due to sickness and death. The negative impact on the capital stock is also evident. Increases in the cost of healthcare deplete savings both individual and national, the pool of potential investible funds. Foreigners are less likely to invest in economies with high HIV/AIDS prevalence rates since the return on their investment may be less certain. In extreme cases there would be a potential for the epidemic to impoverish countries with one possibility being the dismantling of the production process itself. 
There are three development-related issues which arise in this context. The first relates to the scale of production in many of the countries, the second to desired factor intensity of production and the third relates to the industrial policy framework. In each case the HIV/AIDS epidemic seems to be pointing the economy in the wrong direction. In respect of production scale the prognosis is that production volumes across the region will decline making it more difficult to fulfil export orders and raising unit costs. In respect of factor intensity, the argument is that with the absolute decline in the labour supply in a number of sectors, the economies will become more and more capital intensive, making it harder to satisfy employment objectives when the epidemic is brought under control. Finally, in the light of the expected dislocation of existing strategic sectors tourism, for example - the instinct to survive the crisis will lead to policy support for sectors which may not in the longer term be in the best interest of particular countries, for example ones that may be bad for the environment.

\subsubsection{The allocation channel}

One of the important functions of the economic system is to ensure that resources are allocated to the different lines of production in such a way as to minimise the cost of production to the society. Any epidemic which has the potential to cause shortages of critical resources, and/or to skew the use of resources away from crucial lines of production, also holds the potential to impose heavy economic costs on the society under threat. In the case of HIV/AIDS, the issue raised here concerns the volume of the region's foreign exchange which will need to be dedicated to dealing with the disease. To the extent that the therapeutic component of the response to the epidemic will require a reallocation of the region's foreign exchange away from alternative productive uses, there is a likelihood of production shortages and increasing costs in the now foreign-exchange-short sectors. In fact, the exchange rate itself may be under pressure to adjust.

On another level, in the case of HIV/AIDS the very fact that the 15 to 44 age group is the most affected suggests that there is the potential for the region's skilled labour force to be negatively affected. What is more, this negative impact may well deplete the labour force such that the countries may be taken below resource threshold levels, thereby making for an upsetting of factor combinations to the point of inefficiency as well as insufficiency.

\subsubsection{The distribution channel}

The development planners of the Caribbean are in general agreement that one of the main aims of development in the region has been to engender an environment wherein the output of goods and services in the society are equitably distributed. The historical legacy of uneven distributions of income and wealth has remained one of the challenges to policy-makers in the region. The emphasis on improving the education system as well as the attempts to reform the health system have all been predicated on the need to ensure that the weaker, more vulnerable members of our society are not left behind as the economies move forward (Trinidad and Tobago, 2000; UNESCO, 1999).

The existence of the epidemic in other words could lead to income distributions that are even more negatively skewed. In the face of an epidemic like HIV/AIDS which has the potential to weaken the income-base while spurring higher expenditure requirements, it is eminently possible that the lowest income groups will find themselves even worse off once the disease takes root. Not only will their most promising income earners be plucked away, but the young ones who should be replacing them will not live to become earners of income. Although the upper income groups will not be immune to the epidemic, their capacity to protect themselves will have the 
indirect result of widening the gap between the upper and lower income groups as the epidemic gains momentum.

One of the relevant issues here is the access to healthcare for HIV/AIDS patients themselves. The relatively expensive nature of required interventions raises this access question both at the level of the individual and at the level of the broader society. In a context where poverty levels are known to be significant, and where governments are generally under severe fiscal constraints, the care of patients from the lower income brackets has become an important social concern.

\subsubsection{The regeneration channel}

In the face of normally expected increases in population and the usual rise in the expectations of the existing population, the economic system is expected to combine its saving propensity with its technological development to ensure that the system keeps on a path of expansion and increasing sophistication. If the savings capacity and the human capital of the economy are compromised by the HIV/AIDS epidemic, the ability of the economy to regenerate itself at a higher level will also be compromised. This is an important concern for the Caribbean given recent theoretical work coming out of the University of West Indies (UWI) which suggests that, in its interdependence with the economic system, the health system has the potential for converting a downturn into downward spiral (Thomas, 2000). What this means is that the economic managers of the region now have a vested interest in affording preferential treatment to the health system, taking all necessary steps to ensure that no health condition is allowed to reach the point of exerting a negative impact on the economy. The reality, however, is that the HIV/AIDS epidemic threatens to be such a health condition.

It is quite clear therefore that HIV/AIDS is not just a public health crisis but that it is in fact a broader economic crisis. The increasing incidence of this disease threatens to unravel all the development strides made by the economies of the Caribbean during the past three decades. The potential of these already fragile economies to produce, allocate, distribute and regenerate is significantly compromised in the presence of HIV/AIDS. The literature and the experience of other countries which have previously walked this path paint a very grim picture for the Caribbean.

\subsection{Economic impact of HIV/AIDS}

The literature has recognised the bi-causal relationship between HIV/AIDS and economic development. Not only do high prevalence rates hurt the economy but economic stagnation provides an ideal breeding ground for the spread of the disease. Research into the effects of HIV/ AIDS reveals that its impact in terms of its social, human and economic costs is perhaps much more significant than previously thought (Bell et al., 2003). Barnett et al. (2001) capture the many channels of the impact.

HIV/AIDS impacts on economies by creating bottlenecks in the channels of growth and development. It does so by creating distortions in the various markets and sectors of the economic system, particularly the labour market. While economists differ in both philosophical and methodological approaches to economic growth and development, they generally agree on the critical role of accumulation of human and physical capital stock.

In the early works of Harrod (1939), Domar (1946) and Solow (1957), growth is determined by investments in physical capital stock, which result in the accumulation of capital and increases in technology. In this model, total factor productivity (TFP) ${ }^{1}$ is an exogenous factor. In fact, Solow 
(1957) originally attributed more than 90 per cent of the United States per capita growth to exogenous technical progress. Mankiw et al. (1992) extended this framework to include human capital acquired through investments in education which was considered to increase factor productivity. Similar reference can be made to the work of Bernanke and Gürkaynak (2001).

More recently, endogenous growth theorists (Romer 1994) have put forward the idea that there is a direct relationship between productivity gains and investments in research and development through improvements in technology and knowledge creation. Alternatively, there are those who believe that the relationship is not a direct one, but rather that a large proportion of technological advancement comes from 'learning-by-doing'. In the words of one author,

\begin{abstract}
...increases in productivity have to come with the increases in workers' 'human capital' from on-the-job training: the best way to become skilled and productive at handling modern machine technologies is to work at applying them, and improvements in workers' skills and capabilities are social benefits to the economy's productivity that are usually not included in businesses' calculations of their returns on investment.' (De Long, 1997).
\end{abstract}

The increasing incidences of morbidity and mortality from HIV/AIDS and their related complications affect the labour force both quantitatively and qualitatively. It is a well-documented fact that HIV/AIDS is highly concentrated in the 15 to 44 years age group, which represents the most productive working age population and, as a result, impacts most severely on this group. It is reasonable to expect that productivity will fall as infected persons work fewer hours and with decreased effort.

Several aggregate models project significant reductions in economic growth rates for African economies. These modelling exercises typically follow a pattern of reporting 'with AIDS' and 'without AIDS' scenarios. An example is the widely cited ING Barings model produced for the July 2000 HIV/AIDS conference in Durban, which showed that long-term economic growth in South Africa would decline by 0.4 per cent per year due to HIV/AIDS. Recent research, however, suggests that these studies may be too optimistic. What they fail to consider is that by undermining human capacity, HIV/AIDS reduces productivity, disrupts organisations and unravels institutions.

The implication is that the epidemic's effects are more likely to be non-linear. Both theory and practice indicate this is the case. At the aggregate level, the impact of HIV/AIDS has elements consistent with endogenous growth theory. The spread of HIV/AIDS reduces labour productivity, raises private and public consumption, and thereby reduces income and savings. With lower savings, the rate of investment falls, reinforcing the decline in economic growth. The loss of labour productivity occurs because a larger share of the workforce becomes debilitated or dies, causing organisations to lose workers with critical skills. The phenomenon can be likened to 'running Adam Smith in reverse.' Adam Smith argued that the expansion of the market - typically identified as economic growth - creates opportunities for specialisation and the division of labour. The spread of HIV/AIDS reverses that process as organisations experience disruption, and declining income undercuts the earlier gains achieved through specialisation and the division of labour.

Not only does HIV/AIDS affect the macroeconomy negatively but there are also microeconomic implications of high prevalence rates. The potential fall in income for the individual arising from HIV/AIDS-related expenditure can result in a decrease in savings and a reorganisation of consumption patterns. Often it is the case that households are forced to redirect funds away from education, general healthcare for uninfected family members and even from food, into treatment and care for the people living with HIV/AIDS (PLWHA). Government spending is also affected as funds are directed into HIV/AIDS programmes, the opportunity cost being investments in the provision of social services. 
The effect described is felt by the economy in the long run as the quality of human capital diminishes and the accumulation of physical capital is hindered by the fall in investments by firms and by the government. This can translate into negative economic growth as GDP begins to fall.

The methodology used to determine the potential impact of HIV/AIDS falls into two groups. One group uses the indicative approach and infers the impact based on certain facts of the disease, namely the concentration of PLWHAs in the productive adult years, the high cost of treatment, and the impending effects of the disease on individuals (UNDP, 1992; 1993). The second group bases their conclusions on the use of empirical information and results generated by economic models adapted to calculate the impact of HIV/AIDS on the economy. Some of these models include Wharton Econometric Forecasting Associates (WEFA) time series as used by ING Barings (2000), computable general equilibrium (CGE) used in studies done by Arndt and Lewis (2000) and cross-country regressions used by Bonnel (2000).

One of the earliest pieces of work on the economic impact of HIV/AIDS on the economies in the Caribbean was due to Henry and Newton (1994). They estimated that the loss in GDP that would result if the epidemic continued in the manner, in which it was growing, was between 1 per cent and 3 per cent. The more recent study by Camara et al. (1997) for CAREC/UWI estimates the GDP impact of HIV/AIDS based on a number of key assumptions, specifically relating to the derivation of the number of people at risk, the treatment coverage of people infected with HIV/AIDS, and the unit cost of treatment of infected people. This study covered two countries - Jamaica and Trinidad and Tobago - and found that the estimated loss to GDP would reach a level of 4.2 per cent by the year 2005 in those countries.

Inherent in both studies is the recognition that the estimated GDP loss is driven by two key variables: the estimated number of cases in any given year and the average loss of income and output associated with the cases of HIV/AIDS. The Henry and Newton (1994) study used the indicative approach, while the Camara (1997) study was based on the results of sexual surveys and econometric models.

The main results of the Camara (1997) study are summarised in Table 4.2.

Table 4.2 Macroeconomic impact of HIV/AIDS on key variables for Trinidad and Tobago and Jamaica

\begin{tabular}{lccc}
\hline Impact variables & Trinidad and Tobago & Jamaica & Average \\
\hline Gross domestic product & $-4.2 \%$ & $-6.4 \%$ & $-5.3 \%$ \\
Savings & $-10.3 \%$ & $-23.5 \%$ & $-16.9 \%$ \\
Investment & $-15.6 \%$ & $-17.4 \%$ & $-16.5 \%$ \\
Employment in agriculture & $-3.5 \%$ & $-5.2 \%$ & $-4.4 \%$ \\
Employment in manufacturing & $-4.6 \%$ & $-4.1 \%$ & $-4.4 \%$ \\
Employment in services & $-6.7 \%$ & $-8.2 \%$ & $-7.5 \%$ \\
Labour supply & $-5.2 \%$ & $-7.3 \%$ & $-6.3 \%$ \\
HIV/AIDS expenditure & $+25.2 \%$ & $+35.4 \%$ & $+30.3 \%$ \\
\hline
\end{tabular}

Source: Camara et al. (1997)

Theodore (2000) updated the Camara study using new estimates of treatment costs and extended the analysis to cover St Lucia, one of the countries of the Organisation of Eastern Caribbean States (OECS). Table 4.3 presents the new estimates on the GDP impact of HIV/AIDS updated and extended to include St Lucia. 
Table 4.3 GDP impact estimates - alternative scenarios

\begin{tabular}{lccc}
\hline Country & Camara benchmark & Scenario 1 & Scenario 2 \\
\hline Jamaica & $6.2 \%$ & $4.9 \%$ & $3.2 \%$ \\
St Lucia & $4.7 \%$ & $2.1 \%$ & $1.6 \%$ \\
Trinidad and Tobago & $4.2 \%$ & $5.6 \%$ & $4.9 \%$ \\
Average & $5.0 \%$ & $4.2 \%$ & $3.2 \%$ \\
\hline
\end{tabular}

Source: Camara et al. (1997) and author's calculations

The average of the Camara estimates was 5.0 per cent, which is consistent with the assumption currently adopted by the Caribbean Task Force on HIV/AIDS. What is interesting is that on average the countries of the region are currently allocating between 5 and 6 per cent of their national income to health services. It is also noticeable that while for both Jamaica and St Lucia the dramatic fall in treatment costs caused the share of GDP lost to be reduced, in the case of Trinidad and Tobago the opposite happened. The downward effect of the fall in treatment costs was more than compensated for by the upward impact of the significant increase in the number of infected individuals.

McLean (2004) extended the Camara study to the case of Guyana and concluded that the HIV epidemic was poised to impact significantly on the socio-economic fabric of Guyana. The results of the study are summarised in Table 4.4, which shows HIV/AIDS negatively impacting on key macroeconomic variables.

Table 4.4 Economic impact summary - Guyana (2003-15)

\begin{tabular}{lccc}
\hline & Baseline & Model & Difference \\
\hline GDP & $5.00 \%$ & $2.27 \%$ & $-2.73 \%$ \\
Savings & $5.30 \%$ & $2.48 \%$ & $-2.82 \%$ \\
Investment & $9.57 \%$ & $5.83 \%$ & $-3.74 \%$ \\
Employment & $0.59 \%$ & $0.57 \%$ & $-0.02 \%$ \\
Labour supply & $0.76 \%$ & $0.75 \%$ & $-0.01 \%$ \\
\hline
\end{tabular}

Source: McLean (2004) and Laptiste (2004)

It was estimated that growth rates of all the key macroeconomic indicators will be adversely affected by the continuing upward trend in the rates of infection. Moreover, the projected impact is roughly equivalent to central government's allocation to key social services as in the case of Trinidad and Tobago and Jamaica.

Laptiste (2004) examined the impact of HIV/AIDS on the economy of Suriname. The results of this study indicated that the loss in output approximates 1.18 per cent over the period while the negative impact in savings and investment are slightly higher at 1.34 and 1.47 per cent respectively.

It is quite clear from the literature that HIV/AIDS has the potential to reverse the macroeconomic progress of many countries in the Caribbean. While these results should be interpreted with some caution, they all seem to be pointing in the same direction. The negative impact of HIV/AIDS on the macroeconomy of Caribbean states is very real and it therefore cannot be ignored. 


\subsection{Responding to the epidemic: best practices}

The Caribbean region has responded positively to the HIV/AIDS epidemic. Many of the programmes and efforts have been noted as international best practices. These best practices have been observed primarily in the following areas:

- Planning and co-ordination,

- Political commitment,

- Private sector involvement, and

- Institutional responses.

\subsubsection{Planning and co-ordination}

A pan-Caribbean partnership on HIV/AIDS that was established in 2001 has been identified by UNAIDS as a regional best practice in 2004. 'The Pan Caribbean Partnership Against HIV/AIDS (PANCAP) is a unique example of collective action towards the common goal of strengthening the regional response to AIDS in the Caribbean.' (UNAIDS, 2004a)

The Pan Caribbean Partnership Against HIV/AIDS (PANCAP) brings together more than 70 partners to collaborate in the regional response against HIV/AIDS. PANCAP is a multisectoral, multilevel partnership which includes the governments of all countries and territories of the Caribbean region and regional and international organisations from the health, social development, education, economic, culture, tourism and other sectors. Organisations of people living with and affected by HIV, multilateral and bilateral donors, the UN system, government and non-governmental organisations, business organisations, communities of faith and many other types of organisations are members.

Building on joint regional initiatives begun in the 1980s, PANCAP was formally established in 2001 under the umbrella of the Caribbean community (CARICOM). The overarching goal is to, 'curtail the spread of HIV/AIDS and to reduce sharply the impact of AIDS on human suffering and on the development of the human, social and economic capital of the region.' PANCAP functions as a network that encourages each partner to work within its own mandate and areas of comparative advantage, while fostering an environment for partners to pursue their respective programmes in a harmonised and co-ordinated fashion whenever appropriate.

Significant achievements have already resulted from the collaborative regional approach of PANCAP. Since the partnership was established, all 29 countries that comprise the region have joined. The formal structure for governance and operation of the partnership has been established. There is strong political commitment from heads of government of Caribbean member countries, especially the 15 CARICOM states, as well as solid support from leaders of regional and international organisations and institutions for the Partnership for the fight against HIV/AIDS. Caribbean leaders representing PANCAP comprised the largest delegation of any region at the 2001 United Nations General Assembly Special Session on HIV/AIDS (UNGASS), and the efforts of PANCAP leaders have brought the economic and social impact caused by AIDS in the Caribbean to the attention of world leaders and placed it on the global agenda.

Largely as a result of regional and international advocacy by PANCAP leaders, resources from multilateral and bilateral donors, as well as other international sources for the response to HIV/AIDS in the Caribbean have more than quadrupled in the three years since the partnership was formed. The focus of the Caribbean response to HIV/AIDS has shifted from being primarily a health-sector 
responsibility to a truly inter-sectoral response which recognises HIV/AIDS as an economic and development challenge, as well as a health and social issue requiring a broad response from all parts of society. As a result, the HIV/AIDS issue has been dramatically highlighted in the region, and the response significantly accelerated.

The initial and primarily medical response to HIV/AIDS in the Caribbean was spearheaded by the Caribbean Epidemiology Centre (CAREC). CAREC itself began operating in January 1975, less than 10 years before the onset of HIV/AIDS in the region. The Centre has been under the administrative management of the Pan American Health Organization (PAHO) at the request of the Caribbean Health Ministers' Conference held in The Bahamas in 1974. CAREC's mission is to improve the health status of Caribbean people by advancing the capability of member countries in epidemiology, laboratory technology and related public health disciplines through technical co-operation, service, training, research and a well trained, motivated staff. The centre routinely tracks HIV/AIDS numbers and prevalence rates in the region. CAREC has also played a pivotal role in harmonising the reporting structure to bilateral and multilateral donor agencies.

At the national level, with encouragement and support from CAREC, most countries have instituted a national strategic planning process which involves the preparation of a National Strategic Plan (NSP) every five years and this acts as a tool to monitor and guide the response by highlighting the important areas of focus. As part of the planning process most countries in the region have also established a separate body with responsibility for the co-ordination of multisectoral activities and the various micro-level responses on a national level. This body is usually established under the Ministry of Health, as in the case of Jamaica, but is sometimes established as part of the Prime Minister's office, as in The Bahamas, Barbados, and Trinidad and Tobago.

At the international level the response to HIV/AIDS in the Caribbean has been mainly in terms of financial support. We will deal with this later.

\subsubsection{Political commitment}

Governments across the region have committed to funding a significant proportion of the response cost either from recurrent revenues or through international loan facilities. In so doing, governments have either committed significant proportions of already scarce health expenditure budgets or committed future revenues to fight the epidemic. Despite the observed insufficiency of domestic funding to fight the epidemic, this level of domestic expenditure, amounting to about 60 per cent of the cost of the response in some cases, demonstrates clearly the political commitment in the response to the disease.

\subsubsection{Private sector participation}

Efforts have been made in many Caribbean territories to bring the private sector on board in the fight against HIV/AIDS. In Guyana, for example, the private sector is being engaged through separate, but co-ordinated, efforts of two technical partners, the Private Sector Partnership Programme (PSPP) and the Workplace HIV Programme (WHP). The PSPP encourages private enterprises to create a partnership with the Ministry of Health as a means of protecting their human resources by investing in HIV awareness and prevention. By the end of 2007, through this programme, about 43 companies had subscribed to Memoranda of Commitment. Of these companies 23 have established workplace programmes and 15 have HIV workplace policies in place. This initiative can also be considered a best practice since staff from the implementing 
partners has been recruited to help develop and assist with similar programmes elsewhere in the Caribbean and in South America.

Another candidate for best practice in this area is the Jamaican Workplace Education Programme which was initiated by the ILO. Some elements that make this programme a possible best practice are:

- Strong support at the ministerial level,

- Preparation of a consultative and Cabinet-approved national workplace policy on HIV/AIDS,

- Sensitisation and training of more than 75 per cent of ministry staff in voluntary counselling and testing (VCT) and the care and counselling workshops and as PEER facilitators, and

- Appointment of an HIV/AIDS steering committee whose mandate is to include the implementation of this policy.

As a result of this programme the tourism sector in Jamaica has developed a workplace HIV/AIDS policy that was approved by Cabinet in 2007.

\subsubsection{The University of the West Indies response}

The response of the University of the West Indies (UWI) to the epidemic has also been acknowledged as having some key best practice elements. The institution has established the University of West Indies HIV/AIDS Response Programme (UWI HARP) as an accelerated institutional response to the HIV/AIDS epidemic across the entire University - on the campuses in Barbados, Jamaica and Trinidad and Tobago as well as in the extramural centres scattered throughout the Englishspeaking Caribbean. UWI HARP is a multidisciplinary programme dedicated to using the expertise of the university to work with other committed partners in combating HIV/AIDS and mitigating its impact.

UWI HARP was established in August 2001 and consists of a cross-faculty team of staff and students, with invited membership from governments and non-governmental organisations. Task forces have been established on the three campuses to keep the university community, including the transient student population, sensitised about HIV/AIDS and to foster HIV/ AIDS-related curriculum review in all faculties. The UWI HARP is also responsible for continuous updating of the university's HIV/AIDS policy and for facilitating research on the impact and control of the epidemic in the region.

\subsection{International funding for HIV/AIDS}

The 15 countries submitting UNGASS reports from the Caribbean region represent a mix of low, lower-middle, upper-middle and high-income countries, as defined by the World Bank. Haiti is low income, for example, and Guyana is lower-middle income. Barbados, Belize, Dominica, Grenada, St Kitts and Nevis, St Lucia and Trinidad and Tobago are all defined as upper-middle income and yet vary greatly in their ability to invest national resources in public health. Table 4.5 shows the public health expenditure as a percentage of GDP for selected Caribbean countries. It is clear from this table also that Caribbean countries vary in terms of their public allocations to healthcare and GDP per capita. 
Table 4.5 Human development indicators for selected countries

\begin{tabular}{|c|c|c|c|c|c|}
\hline Country & $\begin{array}{c}\text { HDI rank } \\
2007\end{array}$ & $\begin{array}{c}\text { Public expenditure } \\
\text { on health as } \% \\
\text { of GDP (at } \\
\text { current prices) }\end{array}$ & $\begin{array}{l}\text { Total health } \\
\text { expenditure per } \\
\text { capita (PPP int. } \\
\text { US\$, 2005) }\end{array}$ & $\begin{array}{c}\text { GDP per } \\
\text { capita } \\
\text { (PPP US\$, } \\
\text { 2007) }\end{array}$ & $\begin{array}{c}\text { Human } \\
\text { poverty index } \\
\text { (HPI-1 \% } \\
\text { 2007) }\end{array}$ \\
\hline Norway & 1 & $8.3(2004)$ & 4,307 & 53,433 & - \\
\hline Barbados & 37 & $4.5(2004)$ & 1,102 & 17,956 & 2.6 \\
\hline Antigua and Barbuda & 47 & $3.4(2004)$ & 581 & 18,691 & - \\
\hline The Bahamas & 52 & $2.0(2008)$ & 1,404 & 20,253 & - \\
\hline St Kitts and Nevis & 62 & $3.3(2004)$ & 579 & 14,481 & - \\
\hline Trinidad and Tobago & 64 & $2.4(2008)$ & 763 & 23,507 & 6.4 \\
\hline St Lucia & 69 & $3.3(2004)$ & 397 & 9,786 & 6.3 \\
\hline Dominica & 73 & $7.3(2008)$ & 437 & 7,893 & - \\
\hline Grenada & 74 & $3.5(2008)$ & 561 & 7,344 & - \\
\hline Dominican Republic & 90 & $2.3(2008)$ & 356 & 6,706 & 9.1 \\
\hline St Vincent and the Grenadines & 91 & $4.0(2007)$ & 434 & 7,691 & - \\
\hline Belize & 93 & $3.4(2008)$ & 377 & 6,734 & 17.5 \\
\hline Suriname & 97 & $1.5(2006)$ & 325 & 7,813 & 10.1 \\
\hline Jamaica & 100 & $2.8(2004)$ & 210 & 6,079 & 10.9 \\
\hline Guyana & 114 & 2.7 (2006) & 238 & 2,782 & 10.2 \\
\hline Haiti & 149 & $2.9(2004)$ & 71 & 1,155 & 31.5 \\
\hline Niger & 182 & $1.9(2004)$ & 25 & 627 & 55.8 \\
\hline
\end{tabular}

Sources: HDR (2007/08; 2009); UN data (2010); ECLAC (2010)

Table 4.6 HIV/AIDS financing for selected Caribbean countries

\begin{tabular}{lccccccc}
\hline Country & Year & $\begin{array}{c}\text { Total } \\
\text { funds (US\$ } \\
\text { millions) }\end{array}$ & $\begin{array}{c}\text { Domestic } \\
\text { public (\%) }\end{array}$ & $\begin{array}{c}\text { Bilateral } \\
\text { donors (\%) }\end{array}$ & $\begin{array}{c}\text { Global } \\
\text { fund (\%) }\end{array}$ & $\begin{array}{c}\text { United Nations } \\
\text { and all other } \\
\text { multilaterals } \\
(\%)\end{array}$ & $\begin{array}{c}\text { Other } \\
(\%)\end{array}$ \\
\hline Antigua and Barbuda & 2007 & 0.160 & 100 & NA/NR & NA/NR & NA/NR & NA/NR \\
The Bahamas & 2006 & 2.145 & 71.6 & NA/NR & NA/NR & NA/NR & 28.4 \\
Barbados & 2006 & 7.073 & 98 & NA/NR & NA/NR & NA/NR & 2 \\
Cuba & 2007 & 41.927 & 80.9 & 0.0 & 19.1 & 0.0 & 0.0 \\
Dominican Republic & 2007 & 13.737 & 44 & NA/NR & NA/NR & NA/NR & 56 \\
Grenada & 2006 & 1.050 & NA/NR & NA/NR & NA/NR & NA/NR & NA/NR \\
Haiti & 2006 & 70.284 & 0.6 & 67.3 & 24 & 6.5 & 1.55 \\
Jamaica & 2007 & 14.749 & 62.5 & 2 & 35.5 & NA/NR & NA/NR \\
St Lucia & 2007 & 0.772 & 21.6 & 0.0 & 13.9 & 64.6 & 0.0 \\
Trinidad and Tobago & 2006 & 12.148 & 95.6 & 0.0 & 0.0 & 4.4 & 0.0 \\
Turks and Caicos & 2007 & 1.109 & 100 & NA/NR & NA/NR & NA/NR & NA/NR \\
\hline
\end{tabular}

Source: UNAIDS (2008a) 
The response to the HIV/AIDS epidemic in the Caribbean has involved a mix of support by governments in the region, bilateral donors (such as the United States, Canada and European nations), regional and multilateral organisations and non-governmental organisations. Many countries in the region have national AIDS programmes (NAPs) that are supported through these bilateral, regional and multilateral programmes. It is clear from Table 4.5 and Table 4.6 that in most territories the government's financial commitment to the health sector as a whole and in particular to HIV/AIDS spending has been maintained at reasonably high levels by international standards. Despite this, there has been dependence on the support of bilateral and multilateral donor agencies.

\subsection{International donor financing}

Table 4.6 contains some details of the sources of funds available to fight HIV/AIDS in the Caribbean. In most cases, public funds are the most significant source of financing. This raises important concerns related to the sustainability of the response, given the economic vulnerability of some of the Caribbean countries. The dependence on support from bilateral and multilateral international donors is also evident from the data presented in Table 4.6. The Global Fund and the World Bank are the major international investors in HIV/AIDS in the Caribbean, and along with the European Union, these loans and grants affect the relative significance of national expenditures reported under this indicator. Support is also received from the United States Agency for International Development (USAID) and the Inter-American Development Bank (IDB).

\subsection{World Bank}

The World Bank has provided significant support to combat HIV/AIDS in the Caribbean. In June 2001, the bank approved a US\$155 million lending programme for the Caribbean to help countries finance their national HIV/AIDS prevention and control projects. Under this programme, the bank has approved loans to Barbados (2001), the Dominican Republic (2001), Jamaica (2002), Grenada (2002), St Kitts and Nevis (2003), Trinidad and Tobago (2003), the Caribbean Community's (CARICOM) Pan Caribbean Partnership Against HIV/AIDS (PANCAP) (2004), Guyana (2004), St Lucia (2004) and St Vincent (2004). As of December 2006, all countries reporting to UNGASS for the 2006 review receive assistance from the World Bank in support of national AIDS responses, except Antigua and Barbuda, The Bahamas, Cuba, Dominica and Suriname.

\subsection{Inter-American Development Bank}

The Inter-American Development Bank (IDB) has supported HIV/AIDS activities in such countries as The Bahamas, Belize, Guyana, Haiti, Jamaica, Suriname and a regional programme through CARICOM. Moreover, its assistance to support health infrastructure in the region has been important for HIV/AIDS treatment and care programmes.

\subsection{Global Fund to Fight AIDS, Tuberculosis, and Malaria}

The Global Fund to Fight AIDS, Tuberculosis, and Malaria (GFATM) has begun funding programmes throughout Latin America and the Caribbean, with about US\$484 million or almost 10 per cent of disbursed funding worldwide going to this region as of early 2008. Beneficiaries in the Caribbean include Belize, Cuba, the Dominican Republic, Guyana, Haiti, Jamaica and Suriname as well as multicountry programmes for CARICOM, the Caribbean Regional Network of people living with HIV/AIDS 
$(\mathrm{CRN}+)$ and the Organisation of Eastern Caribbean States (OECS). As at December 2006, all countries reporting to UNGASS except Barbados, The Bahamas and Trinidad and Tobago were receiving some form of Global Fund grant (country-specific or as co-recipient on a multi-country grant).

\subsection{US Government and USAID}

Within the federal government, overall US support to combat the HIV/AIDS epidemic in the Caribbean is provided though programmes administered by several US agencies, including the Centers for Disease Control and Prevention (CDC), the National Institutes of Health (NIH), the Department of Labour, the Department of State and the US Agency for International Development (USAID), which has been the lead agency fighting the epidemic abroad since 1986.

US government funding to combat HIV/AIDS in the Caribbean and Latin America has increased in recent years. Foreign aid to the region rose from US $\$ 47$ million in 2004 to an estimated US\$139 million for 2008. For 2009, the administration requested US\$139 million, with US\$92 million for Haiti and US\$20 million for Guyana. The balance of the request for other countries is through the child survival and health (CSH) foreign assistance funding account. In the Caribbean, USAID provides HIV/AIDS assistance through both bilateral and regional programmes, and is an active member of the Pan Caribbean Partnership Against HIV/AIDS. As part of its Caribbean regional programme, USAID has initiated a programme focusing on Caribbean countries that do not have a permanent USAID presence: Trinidad and Tobago, Suriname, St Kitts and Nevis, St Lucia, St Vincent and Grenadines, Grenada, Antigua and Barbuda, Dominica and Barbados.

A recent report from the World Bank (2005) noted the good fortune of a significant flow of external resources but expressed concern about their ability to manage such flows and deal with as many as eight donors and agencies working on HIV/AIDS. The potential inflow of US\$460 million (shown in Table 4.8) represents a significant influx of financial resources, in a comparatively short period of time, to relatively small island-states. The three principal funders are the Global Fund, the

Table 4.7 US HIV/AIDS assistance: funding in Latin America and the Caribbean (US\$ millions)

\begin{tabular}{|c|c|c|c|c|c|c|}
\hline Country & 2004 & 2005 & 2006 & 2007 & $\begin{array}{c}2008 \\
\text { (est) }\end{array}$ & $\begin{array}{c}2009 \\
\text { (request) }\end{array}$ \\
\hline Belize & - & - & 0.2 & 0.5 & - & - \\
\hline Costa Rica & - & - & 0.2 & 0.2 & - & 0.3 \\
\hline Dominican Republic & 5.3 & 5.5 & 6.1 & 6.5 & 5.0 & 5.8 \\
\hline El Salvador & 0.5 & 0.5 & 1.1 & 2.2 & 2.0 & 2.2 \\
\hline Guatemala & 0.5 & 0.5 & 1.3 & 3.4 & 3.5 & 3.5 \\
\hline Guyana & 6.8 & 14.8 & 18.0 & 25.3 & 20.0 & 20.0 \\
\hline Haiti & 18.3 & 44.1 & 47.3 & 77.3 & 20.0 & 92.0 \\
\hline Honduras & 4.2 & 5.2 & 5.2 & 5.8 & 5.0 & 5.0 \\
\hline Jamaica & 1.3 & 1.3 & 1.5 & 1.3 & 1.2 & 1.2 \\
\hline Nicaragua & 0.5 & 0.5 & 1.0 & 2.2 & 1.5 & 1.5 \\
\hline Panama & - & - & - & 0.5 & - & - \\
\hline Central America Programme & 5.0 & 5.4 & 5.5 & 1.7 & 3.4 & 1.0 \\
\hline Caribbean Regional Programme & 4.7 & 4.7 & 5.9 & 6.6 & 5.7 & 5.8 \\
\hline Total & 47.1 & 82.5 & 93.3 & 125.5 & 67.3 & 138.3 \\
\hline
\end{tabular}

Sources: USAID (2008) and US Department of State (2010) 
Table 4.8 Major donors to Caribbean countries in the fight against HIV/AIDS, 2002-05 (computed)

\begin{tabular}{lll}
\hline & Amount (US\$) & Countries \\
\hline World Bank & $\begin{array}{l}\text { 117.65 million (mix of loan } \\
\text { and grant) over 5 years }\end{array}$ & $\begin{array}{l}\text { Barbados, Dominican Republic, Grenada, } \\
\text { Guyana, Jamaica, St Kitts and Nevis, St Lucia, } \\
\text { St Vincent and the Grenadines, Trinidad and } \\
\text { Tobago, PANCAP }\end{array}$ \\
US Government & $\begin{array}{l}\text { 120.9 million grant } \\
\text { over 2 years (2004, 2005 only) }\end{array}$ & $\begin{array}{l}\text { Dominican Republic, Guyana, Haiti, Jamaica, } \\
\text { Regional }\end{array}$ \\
The Global Fund & $\begin{array}{l}\text { 225.176 million grant } \\
\text { over 5 years }\end{array}$ & $\begin{array}{l}\text { Belize, Cuba, Dominican Republic, Guyana, } \\
\text { Haiti, Jamaica, Suriname, OECS, PANCAP, } \\
\text { CRN+. }\end{array}$ \\
\hline
\end{tabular}

World Bank and the US President's Emergency Plan for AIDS Relief (PEPFAR). As indicated, the programmes are operating in several countries at the same time.

According to the report of the World Bank, a review team identified challenges of harmonisation and alignment in every country. On the financing side, donor financing - particularly the World Bank and Global Fund - is not aligned with country budget cycles and systems. Despite an explicit interest in harmonisation and alignment, they are still focused on financing projects rather than broader national programmes. The governance arrangements, on the other hand, tend to be fragmented due to the superimposition of the National AIDS Authorities and the country co-ordinating mechanism of the Global Fund. These duplicate mechanisms increase costs (and in smaller countries often involve the same people).

Financial reporting and audit reports, disbursement requests and regular reporting follow donor-defined timelines and procedures rather than national ones. Pre-execution assessments and appraisals for fiduciary and implementation arrangements are often duplicated. There are examples in the region of effective, country-driven harmonisation among donors, such as in Guyana where the World Bank, Global Fund and IDB's health programmes share a common implementation unit, common procurement guidelines, a single audit for all projects and a harmonised financial reporting system. Such a model should be replicated, but it takes local leadership and commitment.

The international commitment and support to stem the epidemic in the region has grown considerably over time, and the region has made progress in the treatment and care of people infected with HIV/AIDS. Nevertheless, the quality and scope of surveillance, prevention and treatment programmes in the region vary because of unequal socioeconomic conditions. Also, there is much room for improvement in the capacity to manage such funds effectively in the fight against HIV/AIDS.

\subsection{Effectiveness of expenditure}

The effectiveness of expenditure on HIV/AIDS could be determined by the outcome of expenditures in terms of reductions in the prevalence rates and changes in the sexual practices of the target populations. In July 2005, UNAIDS published and disseminated Guidelines on Construction of Core Indicators to aid in reporting on the progress made from intervention activities. The guidelines were also intended to ensure transparency of the process used by national governments to prepare 


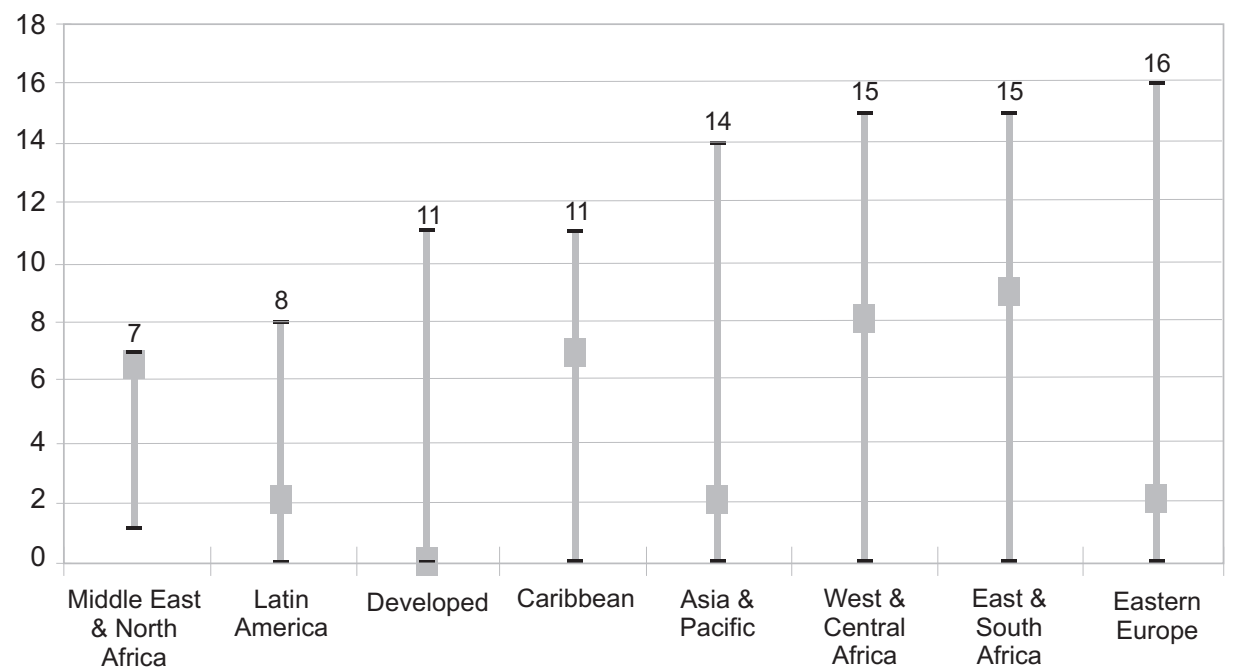

Figure 4.1 Range and median of indicators reported by countries within each region, 2006 Source: UNAIDS (2007b)

their progress reports. UNGASS reporting includes 17 indicators for generalised epidemics and 9 for concentrated/low-prevalence epidemics. The average range and number of indicators reported compared well with other world regions, as can be seen from Figure 4.1.

The graph shows that the Caribbean region holds a favourable position in terms of the number of indicators reported when compared with other regions. These indicators are widely recognised as the 'litmus test' for gauging national programme effectiveness, within a regional and global context. Baseline data are now increasingly available for key UNGASS indicators. A summary of UNGASS indicators for selected Caribbean countries for 2008 is included in the Appendix.

The latest round of national UNGASS reports reveal increasing political commitment compared with previous years, along with marked programme expansion, in part reflecting significant increases in external donor financing. Programme expansion is manifested in the broadening of sectors formally involved in national responses, reflected in the multi-sectoral nature of National AIDS Co-ordinating bodies, often appointed by Cabinet and located in the Office of the Prime Minister. In some cases, National HIV and AIDS Councils (or Commissions/Directorates) are chaired by the Prime Minister, or President. Results from the National Commitment and Policy Index (NCPI) show governments are committed to re-orienting expanded national responses along the guiding principle of the 'Three Ones' in a bid to harmonise external support efforts.

The Three Ones principle advocates:

1. One national co-ordinating authority,

2. One national strategic framework, and

3. One monitoring and evaluation system.

While the NCPI shows a high level of commitment among governments to the Three Ones, UNGASS reports in general indicate a low level of efficacy on the part of National AIDS Co-ordinating bodies to actually manage harmonisation on the ground. Countries in the region have yet to take pro-active steps to encourage harmonisation, such as announcing the date and agenda for 
joint annual reviews of national strategies and M\&E plans, while warding off numerous reviews organised separately by external stakeholders. As a result, external stakeholders continue with unilateral project review missions, often over-loading national staff.

Due, in part, to financial support from the Global Fund to fight AIDS, tuberculosis and malaria (GFATM), as well as technical and financial support from the Clinton Foundation and the World Bank, UNGASS reports show significant gains in the expansion of free ARV treatment services between 2006 and 2007, and renewed emphasis being placed on prevention during 2006-07. Prevention efforts have focused on the development of targeted behaviour change interventions among vulnerable populations, and public awareness campaigns for the reduction of stigma and discrimination.

By late 2005, many countries were better placed to report on national progress across a broader range of UNGASS goals and targets. As a result, the majority of 2006 reports from the Caribbean include data on a range of nine or more UNGASS indicators. Reporting is strongest for treatment, scale up and prevention of mother to child transmission (PMTCT). Data on prevention education programmes in general are weak. Both treatment and prevention service coverage data are reported largely in terms of counts, rather than population estimates; quality coverage data are weak throughout the region. In general, service delivery data indicate weak programming in the diagnosis, counselling and treatment of sexually transmitted infections (STI) and poor public education around the benefits of HIV and STI testing in general.

In addition, many countries are striving to learn from the experience of countries such as The Bahamas, where it was recognised early on that tackling the HIV epidemic, also meant tackling the issue of crack cocaine. Additional data sources beyond UNGASS indicate that advances are being made in scaling up prevention education and VCT promotion among vulnerable communities. However, UNGASS reports show weak data on prevention programme coverage. Community service organisations and NGOs have gained access to vulnerable communities in contexts where government agencies have failed to reach most-at-risk populations. As countries prepare to scale up towards universal access to key services, the involvement of community-based organisations (CBOs) in aggregating data on numbers reached, and in setting and reaching coverage targets, will be crucial to success.

Access to ARV drugs has improved significantly in a number of countries, although universal access to treatment in poorer resource-limited countries could take years to achieve. Brazil has been a model in the developing world in terms of offering antiretroviral (ARV) treatment to all people living with HIV, and the survival rate of AIDS patients in the country has risen significantly because of this. AIDS mortality has also declined in other countries providing universal coverage for ARV treatment, including Argentina, The Bahamas, Barbados, Costa Rica, Cuba and Panama.

According to a joint 2007 report issued by UNAIDS, UNICEF and the WHO, some 355,000 people were receiving ARV treatment in Latin America and the Caribbean in 2006, or 72 per cent of those needing it. The report also cautioned, however, that coverage declined slightly in the second half of 2006, and suggested that the increase in need is not being matched by an increase in the number of people being treated.

In a number of smaller poorer countries in the region, particularly in the Caribbean and Central America, the percentage of people receiving ARV treatment is much less than the regional average. In Haiti, almost 37 per cent of those needing ARV treatment were receiving in 2006, while in the neighbouring Dominican Republic, 36 per cent of those needing treatment were receiving it. Other countries where under 50 per cent of those in need of ARV treatment were 
receiving it include El Salvador, Honduras and Trinidad and Tobago. While these numbers are low compared with the regional average, they still reflect a large increase in ARV treatment for these countries. It should also be pointed out that in the Caribbean only first line treatment is readily available. For although, relatively speaking, the Caribbean is not a poor region, the prevalence of fiscal deficits means that the option of moving to second line ARVs has not been available to the region. Concerns have been expressed in respect of drug resistance but there has been no policy development on this matter.

Bilateral and multilateral agencies in the Caribbean support a regional approach in dealing with the epidemic in part because governments are either too small or too poor to respond adequately. Minimal infrastructure, weak institutional capacity and poverty have hampered efforts to respond to the epidemic in several countries. In order to overcome these difficulties, the Caribbean Community (CARICOM) has co-ordinated a regional approach to combat AIDS. In 1998, the CARICOM Secretariat chaired a Caribbean task force on HIV/AIDS that developed a strategic plan for the region. In 2002 CARICOM and PANCAP, the partnership launched the previous year, developed a 2002-06 Strategic Framework and a Plan of Action to respond to the epidemic. The Pan American Health Organization and its Caribbean Epidemiology Center (CAREC) have provided technical assistance to help implement the Strategic Plan, and donors have included UNAIDS and the World Bank and bilateral donors such as the United States.

\subsection{Conclusion}

Despite the progress made during the last decade, the region still faces some challenges in the response to HIV/AIDS in the following areas:

1. Data and indigenous research,

2. Access to high risk populations,

3. Monitoring and Evaluation,

4. Surveillance, and

5. Financing.

As the most recent UNAIDS report has shown, significant strides have been made in the response to HIV/AIDS in the Caribbean in recent years (UNAIDS, 2009). This is due to a combination of efforts by the respective governments, by key regional agencies and by the international community. However, given the apparent levelling off in incidence, there is much room for future research, especially pertaining to the microeconomic impact of the disease. Much work also needs to be done at the national and regional levels on tracking the sources and uses of funds available in the fight against HIV/AIDS. We support the call for the preparation of Annual National Health Accounts for all countries. This has been done for a sample of countries under the initiative of UNAIDS (UNAIDS, 2004b). Included among these countries were Belize and Guyana.

Perhaps the most important requirement is for a concerted effort to tailor the HIV/AIDS response towards the most at-risk populations who are usually the sub-groups that are most in need of intervention activities, but which because of stigma and discrimination are often excluded from these response activities. Limited data on the impact of interventions on these high risk population groups are only recently emerging.

In many territories the data show that the epidemic is beginning to stabilise. AIDS deaths are on the decline (Table 4.1) and prevalence rates have started to decrease in some cases. International 
financial support and governments' commitment are increasing. HIV/AIDS is no longer an automatic death sentence given the availability and increased access to ARV treatment. PLWHAs can now enjoy reasonably long life spans and so still contribute to productivity and national output. Given these trends the macroeconomic impacts previously estimated will have to be updated.

What this study has shown is that HIV/AIDS has become virtually endemic to the Caribbean and that the impact on the economies and the social fabric of the different countries is decidedly unwholesome. The ray of hope, however, is that a successful response to the epidemic remains within the capacity of the people of the region. As long as the region maintains the political commitment that has been shown, as long as the region comes to terms with the stigma and discrimination that has reared its head and as long as each country concentrates more on the most at risk groups there is no reason why, in spite of its small size and attendant vulnerability, the countries of the Caribbean cannot be among the first to be able to claim that they have begun to overcome the terrible scourge that is HIV/AIDS.

\section{Note}

1. Total factor productivity refers to efficiency improvements (or declines) which are not attributable solely to either one or the other of the two factor inputs (labour and capital), but rather to their combination in production.

\section{References}

Arndt, Channing and Jeffrey D Lewis (2000). 'The Macro Implications of HIV/AIDS in South Africa: A Preliminary Assessment'. The South African Journal of Economics 68 (5): 856-887. Available at: http://www.worldbank.org/ afr/wps/wp9.pdf

Barnett, Tony and Colette Clement (2005). 'HIV/AIDS Impact: so where have we got to and where next?' Progress in Development Studies 5 (3): 237-247.

Barnett, Tony et al. (2001). 'The Social and Economic Impact of HIV/AIDS in Poor Countries: A Review of Studies and Lessons'. Progress in Development Studies 1 (2): 151-170.

Bell, Clive et al. (2003). The Long-Run Economic Costs of AIDS: Theory and an Application to South Africa. World Bank Policy Research Working Paper No. 3152. Washington, D.C.: the World Bank Group. Available at: http://siteresources.worldbank.org/INTHIVAIDS/Resources/375798-1103037153392/BeDeGe_BP_total2.pdf

Bernanke, Ben and Refet S Gürkaynak (2001). Is Growth Exogenous? Taking Mankiw, Romer and Weil Seriously. National Bureau of Economic Research (NBER) Working Paper No. 8365. Cambridge, Massachusetts: NBER. Available at: http://home.aubg.bg/faculty/Didar/ECON\%20402/ISLTgrowthExoBernankeGurkaynak.pdf

Bonnel, René (2000). Economic Analysis of HIV/AIDS. ADF 2000 Background Paper, the World Bank. Washington, D.C.: the World Bank Group.

Camara, Bilali et al. (1997). Modelling and Projecting HIV and its Impact in the Caribbean: The Experience of Trinidad and Tobago and Jamaica. CAREC and UWI.

CAREC (2002). Annual Report 2002. Caribbean Epidemiology Centre. Available at: http://www.carec.org

CAREC (2006). Annual Report 2006. Caribbean Epidemiology Centre. Available at: http://www.carec.org

De Long, D (1997). Building the Knowledge-Based Organization: How Culture Drives Knowledge Behaviors. Working Paper, Centre for Business Innovation, Ernst and Young LLP. Boston, Massachusetts.

Domar, Evsey (1946). 'Capital Expansion, Rate of Growth and Employment'. Econometrica 14 (2): 137-47. Available at: http://www.ie.ufrj.br/hpp/intranet/pdfs/domar1946.pdf

ECLAC (2010). Website of the Economic Commission for Latin America and the Caribbean. CEPALSTAT Databases and Statistical Publications [cited 15 March 2010]. Available at: http://websie.eclac.cl/infest/ajax/ cepalstat.asp?carpeta=estadisticas\&idioma=i 
Haacker, Markus (2002). Modelling the Macroeconomic Impact of HIV/AIDS. IMF Working Papers 02/195. Washington, D.C.: IMF. Available at: http://imf.org/external/pubs/ft/wp/2002/wp02195.pdf

Harrod, Roy F (1939). 'An Essay in Dynamic Theory'. The Economic Journal 49 (193): 14-33. Available at: http:// www.sonoma.edu/users/e/eyler/426/harrod1.pdf

Henry, Ralph, and Elizabeth Newton (1994). 'AIDS Costs in Trinidad and Tobago'. Studies in International Comparative Development 29 (4): 68-89.

ING Barings (2000). Economic Impact of AIDS in South Africa: A Dark Cloud on the Horizon. Johannesburg: ING Barings (South African Research).

Inter-American Development Bank (IDB) (2004). Resource Requirements to Fight HIV and AIDS in Latin America and the Caribbean. Sustainable Development Department Technical Paper Series. Washington, D.C.: IDB. Available at: http://idbdocs.iadb.org/wsdocs/getdocument.aspx?docnum=354500

Jamison, Dean T et al. (2006). Disease Control Priorities in Developing Countries, Second Edition. New York: Oxford University Press and Washington, D.C.: the World Bank Group. Available at: http://www.dcp2.org/pubs/DCP

La Foucade, Althea D et al. (2006). 'The Economic Impact of HIV/AIDS in the Caribbean'. In SR Prabhu (ed) HIV/ AIDS in Dental Practice: An Illustrated Handbook for Caribbean Dental Practitioners.

Laptiste, Christine (2004). Estimating the Economic Impact of HIV/AIDS in Suriname. SIRHASC Report, the Health Economics Unit (HEU), UWI, St Augustine. Available at: http://www.hiv.gov.gy/edocs/caricom_as_ hivimpact_sr.pdf

Mankiw, Gregory et al. (1992). 'A Contribution to the Empirics of Economic Growth'. Quarterly Journal of Economics 107 (2): 407-437. Available at: http://www.uac.pt/ amenezes/macroeconomiaII/macroeconomiaII_20062007/ papers/mrw1992.pdf

McLean, Roger (2004). Modelling and Projecting the Economic Impact of HIV/AIDS in the Caribbean: The Case of Guyana. SIRHASC Report, the Health Economics Unit (HEU), UWI, St Augustine.

PANCAP (2002). The Caribbean Regional Strategic Framework for HIV/AIDS, 2002-2006. Available at: http://www. caricom.org/jsp/projects/hiv-aidsstrategicframework.pdf

Romer, Paul M (1994). 'The Origins of Endogenous Growth'. Journal of Economic Perspectives, American Economic Association 8 (1): 3-22. Available at: http://www.development.wne.uw.edu.pl/uploads/Courses/ de_jt_romer1.pdf

Solow, Robert (1957). 'Technical Change and the Aggregate Production Function'. Review of Economics and Statistics 39 (3): 312-320. Available at: http://pub.paran.com/econ22/Solow(1957).pdf

Sullivan, Mark P (2006). AIDS in the Caribbean and Central America. CRS Report for Congress. Available at: http:// fpc.state.gov/documents/organization/62680.pdf

Theodore, Karl (2000). HIV/AIDS in the Caribbean. HEU Discussion Paper no. 1. The University of the West Indies (UWI), St Augustine.

Theodore, Karl (2001). HIV/AIDS in the Caribbean: Economic Issues - Impact and Investment Response. CMH Working Paper Series, Paper No. WG1: 1. Available at: http://www.whoindia.org/LinkFiles/Commision_on_ Macroeconomic_and_Health_01_01.pdf

Theodore, Karl and Althea D La Foucade (2001). 'The Impact of HIV/AIDS on Social Safety Nets: What Can the Caribbean Expect?' Revista CIESS. Available at: http://129.3.20.41/eps/hew/papers/0110/0110003.pdf

Thomas, Andy (2000). Towards a Framework for Examining the Interrelationship Between Health and the Economy. MSc. Thesis, Department of Economics, University of the West Indies, St Augustine, Trinidad and Tobago.

Trinidad and Tobago Ministry of Finance (2000). 2000/2001 Budget Speech. Port of Spain, Trinidad. Available at: http://www.finance.gov.tt/documents/publications/pub2.pdf

UNAIDS (2004a). A Study of the Pan Caribbean Partnership Against HIV/AIDS (PANCAP): Common Goals, Shared Responses, UNAIDS Best Practice Collection, December 2004. Geneva: UNAIDS. Available at: http://data.unaids. org/publications/IRC-pub06/jc1089-pancap_en.pdf 
UNAIDS (2004b). National Spending for HIV/AIDS, 2004. Geneva: UNAIDS. Available at: http://data.unaids.org/ publications/IRC-pub06/jc1023-nationalspending2004_en.pdf

UNAIDS (2005). Monitoring the Declaration of Commitment on HIV/AIDS: Guidelines on Construction of Core Indicators, July 2005. Geneva: UNAIDS. Available at: http://data.unaids.org/Publications/IRC-pub06/jc1126constrcoreindic-ungass_en.pdf

UNAIDS (2006a). Report on the Global AIDS Epidemic, 2006. Geneva: UNAIDS. Available at: http://www.unaids. org/en/KnowledgeCentre/HIVData/GlobalReport/2006/default.asp

UNAIDS (2006b). UNGASS Country Progress Reports for the Caribbean, 2006. Available at: http://www.unaids.org/ en/KnowledgeCentre/HIVData/CountryProgress/2005 CountryProgress.asp

UNAIDS (2007a). Caribbean AIDS Epidemic Update: Regional Summary, 2007. Geneva: UNAIDS. Available at: http://data.unaids.org/pub/Report/2008/jc1528_epibriefs_caribbean_en.pdf

UNAIDS (2007b). Keeping Score: AIDS Responses in the Caribbean, 2007. Geneva: UNAIDS. Available at: http://data. unaids.org/pub/Report/2007/20070605_Keeping_score_Caribbean_UNGASS_2006_en.pdf

UNAIDS (2008a). Report on the Global AIDS Epidemic, 2008. Geneva: UNAIDS. Available at: http://www.unaids. org/en/KnowledgeCentre/HIVData/GlobalReport/2008/2008_Global_report.asp

UNAIDS (2008b). UNGASS Country Progress Reports for the Caribbean, 2008. Available at: http://www.unaids.org/ en/KnowledgeCentre/HIVData/CountryProgress/2007CountryProgressAllCountries.asp

UNAIDS (2009). 2009 AIDS Epidemic Update, UNAIDS, Geneva, 2010.

UNAIDS, UNICEF and WHO (2007). Towards Universal Access: Scaling up Priority HIV/AIDS Interventions in the Health Sector, Progress Report, April 2007. Geneva: WHO. Available at: http://data.unaids.org/pub/ Report/2007/20070925_oms_progress_report_en.pdf

UNdata Website (2010). [cited 15 March 2010]. Available at: http://data.un.org

UNDP (1992). The Economic Impact of the HIV Epidemic, Issues Paper 2, 1992. New York: UNDP. Available at: http://www.undp.org/hiv/publications/issues/english/issue02e.htm

UNDP (1993). Economic Implications of AIDS in Asia eds. David Bloom and Joyce Lyons. New Delhi, India: UNDP.

UNDP (2007). Human Development Report 2007/2008 - Fighting Climate Change: Human Solidarity in a Divided World. New York: UNDP. Available at: http://hdr.undp.org/en/media/HDR_20072008_EN_Complete.pdf

UNDP (2009). Human Development Report 2009 - Overcoming Barriers: Human Mobility and Development. New York: UNDP. Available at: http://hdr.undp.org/en/media/HDR_2009_EN_Complete.pdf

UNESCO (1999). UNESCO Statistical Yearbook 1999, UNESCO Institute for Statistics.

USAID (2008). Available at http://www.usaid.gov/our_work/global_health/aids/Funding/factsheets/lac.html

US Department of State (various dates). Congressional Budget Justification for Foreign Operations, Issues FY 2007, FY 2008 and FY 2009.

World Bank (2005). HIV/AIDS in the Caribbean Region: A Multi-Organization Review, Final Report. Washington, DC: the World Bank Group. Available at: http://siteresources.worldbank.org/INTHIVAIDS/Resources/3757981103037153392/CaribbeanReview.pdf 
